\title{
The Great Recession and new class voting in Iceland
}

\author{
Agnar Freyr Helgason, Postdoctoral Fellow, Faculty of Political Science, \\ University of Iceland
}

\begin{abstract}
Conventional wisdom suggests that occupational class plays a limited role in explaining vote choice in Iceland. In this paper, we argue that the death of class in Icelandic politics may be premature and that it still plays a role in structuring political preferences and party choice. While the importance of the traditional class cleavage may have declined to the point of irrelevance, we suggest that there is a new type of class voting in Iceland, containing both a vertical and a horizontal component. Furthermore, we argue that the Great Recession played a critical role in increasing the strength of class voting around this new class schema, both because of the conflict around economic issues it generated, but also because of its facilitation of the formation and success of new parties. We test our main hypotheses using multinomial logistic regression on data from the Icelandic National Election Study from 1999 to 2016 and apply a modified measure of cleavage strength, which we refer to as "Full Kappa". Our results suggest that class voting is alive and well in Iceland and that its strength has increased following the Great Recession.
\end{abstract}

Keywords: Great Recession; political behavior; class voting; vote choice.

\author{
Icelandic Review of Politics and Administration Vol 14, Issue 3 (159-182) \\ (C) 2018 Contact: Agnar Freyr Helgason, afh@hi.is \\ Article first published online December 13th 2018 on http://www.irpa.is \\ Publisher: Institute of Public Administration and Politics, Gimli, Sæmundargötu 1, 101 Reykjavík, Iceland \\ Stjórnmál \& stjórnsýsla 3. tbl. 14. árg. 2018 (159-182) Fræđigreinar \\ (C) 2018 Tengiliður: Agnar Freyr Helgason, afh@hi.is \\ Vefbirting 13. desember 2018 - Birtist á vefnum http://www.irpa.is \\ Útgefandi: Stofnun stjórnsýslufræđa og stjórnmála, Gimli, Sæmundargötu 1, 101 Reykjavík \\ DOI: https://doi.org/10.13177/irpa.a.2018.14.3.1 \\ This work is licensed under a Creative Commons Attribution 3.0 License.
}




\section{STJÓRNSÝSLA}

\section{Introduction}

According to conventional wisdom, class voting is not an important aspect of Icelandic politics. While studies suggest that it played an important role during the mid-20th century, it is generally considered, at least implicitly, mostly irrelevant to contemporary politics (Harðarson 2004; Indriðason, Önnudóttir, Pórisdóttir, \& Harðarson 2017; Önnudóttir, Schmitt, \& Harðarson 2017). Instead, current scholarship emphasizes the importance of specific issue positions and election-specific factors in determining voting behavior in the Icelandic case, with structural cleavages, on the whole, playing a limited role. In essence, voters are assumed to have moved into the Michigan funnel of causality in their voting behavior (Campbell et al. 1960).

In this paper, we argue that the verdict on the death of class voting in Iceland may be premature. Although the importance of the traditional class cleavage may have decreased in recent decades, we suggest that occupational class still plays a latent role in structuring political preferences and party choice. Employing recent advances in the study of class voting (Oesch 2006) and the effects of occupational class on political behavior (Kitschelt \& Rehm 2014), we hypothesize that there is both a vertical component to class voting in Iceland, as classes with different levels of economic resources diverge in their voting behavior, and a horizontal component to class politics, as classes which face different occupational task structures, differ in their authoritarian and libertarian views on society. Comparing the eight class schema that results from such a classification to the conventional divide between manual and non-manual workers, suggests that divides within the old classes are no less important than between them.

We propose, moreover, that the recent global financial crisis may have acted as a catalyst in realigning Icelandic politics around this new class schema. The Great Recession, as it is commonly referred to, caused the collapse of most major financial institutions in Iceland and led to sharp increases in unemployment and economic insecurity, as well as bringing about substantial cuts to government spending and increases in taxation (Ólafsson 2016). As the economic crisis developed, it led to a full blown political crisis, with trust in political parties and government plummeting, large scale street protests, electoral volatility greatly increased between elections, and the introduction of several new parties into parliament (Ólafsson 2016; Bernburg 2016; Indriðason et al. 2017; Önnudóttir et al. 2017). By putting socioeconomic issues squarely on the political agenda and causing substantial electoral volatility, we argue that the Great Recession should have the potential to transform the relationship between class and voting in Icelandic politics. As such, Iceland in the period after the Great Recession can be considered a "most-likely" case for increases in class voting (George \& Bennett 2005)

We test the hypotheses put forward in the paper using survey data from the Icelandic National Election Study. We employ logistic and multinomial logistic regression to evaluate models of party choice, testing both the development of traditional class voting with data from 1983 to 2016, as well as whether a new class schema has gained relevance in Icelandic politics, with data from 1999 to 2016. We summarize the strength of class voting with a novel measure we call "Full-Kappa", which is based on a measure developed 
in the context of economic voting (Duch \& Stevenson 2008) and income-based voting (Helgason 2016). The measure is similar to the well-known Kappa measure (Manza, Hout, \& Brooks 1995), although it goes beyond it in several ways, most importantly by using the covariate profiles of all respondents to derive a measure of cleavage strength, rather than using the covariate profile of a single, hypothetical "modal" respondent.

There are two primary findings we wish to highlight. First, we find support for the importance of class voting based around a new class schema, which structures party choice in Iceland. Before the Great Recession the strength of this new class voting was moderate, especially compared to the strength of the traditional class cleavage in the 1980s. Second, we find that after the Great Recession, the strength of new class voting has increased substantially, with the Conservative Independence Party being the most polarizing party among classes, i.e. its support among occupational classes has diverged considerably (as opposed to being uniform among different classes). While the centerleft Social Democratic Alliance was the other primary polarizing party before the crisis, the newly formed Pirate Party took up that role in the 2016 elections.

The paper innovates on prior research in several ways. Empirically, the paper updates and extends prior work on class voting in Iceland, evaluating its development before and after the Great Recession, as well as applying a more sophisticated measure of cleavage strength than in prior research. Theoretically, we argue that economic crises can be particularly consequential for class voting, in that they can bring about intense political conflicts about the welfare state and economic insecurity, as well being catalysts for the establishment of new political parties. Thus, economic crises should be especially likely to increase the strength of class voting. Finally, methodologically, we extend a measure previously employed in a different context to the case of class voting. The measure, which we refer to as "Full Kappa", improves upon the well-known Kappa-index and has the potential to be employed as a generic measure of cleavage strength.

\section{Traditional class voting in historical context}

Class and class politics played a critical role in the formation of European party systems in the early 20th century (Lipset \& Rokkan 1967). While the mechanism by which class affects political behavior is often unspecified, conventional accounts highlight the importance of class identity, the structure of the industrial economy, union density, and economic self-interest, in creating and sustaining a strong affinity between class position and vote choice throughout its golden era (Evans 2000). Lipset's (Lipset 1960, 1981, 220-224) claim that "in virtually every economically developed country the lower income groups vote mainly for parties of the left" highlights the directional component of this relationship, although the occupational distinction between manual and nonmanual workers is more commonly theorized to be the basis for traditional class voting (Evans 2017).

Much like in neighboring countries, the development of the Icelandic party system was strongly affected by the class cleavage. From the 1930s up until the Great Recession, the Icelandic party system was dominated by four parties, which were originally 
formed to represent the interests of specific socioeconomic cleavages: The right-wing Independence Party (business owners), the Center-Rural Progressive Party (farmers), and two left-wing parties, the Social Democratic Alliance and the Left-Green Movement, which trace their roots to two working class parties, the Social Democratic Party and the Communist Party (Harðarson 1995). Although these parties were commonly joined in parliament by short-lived fifth or even sixth parties from the 1970s onward, the Icelandic party system was overall a four-party system for most of the 20th century, making it in some ways distinct from the other Nordic party systems, which have generally had more parties represented in parliament (Bengtsson, Hansen, Harðarson, Narud, \& Oscarsson 2014).

The demise of the class cleavage in the politics of advanced democracies in the latter half of the 20th century has been well documented (Franklin, Mackie, \& Valen 1992; Evans 1999; Clark \& Lipset 2001; Knutsen 2006; Manza \& Brooks 2008). At the micro level, social classes have become more cross-cutting due to increased social mobility, affluence, individualization, and education, which reduces the structuring impact of class on political behavior (Evans 2017), while at the macro level, political parties have increasingly converged on policy positions with respect to the class cleavage, which again reduces its salience in structuring vote choice (Evans \& de Graaf 2013). As some have argued, the basis for such partisan convergence on class related issues could be attributable to increasing globalization in recent decades, which has to some extent removed macroeconomic policymaking from the electoral arena (Streeck 2009; Häusermann \& Kriesi 2015). In any case, whether driven by a micro-level bottom-up process, or a macro-level top-down process, the observable implications are the same - a declining influence of class on voting behavior.

Existing research on the Icelandic case, suggests that class voting followed a similar pattern throughout the 20th century. Thus, based on survey data from 1983 of paternal political behavior during respondents' youth, Harðarson (1995) suggests that class voting may have been strong in the 1930s and 1940s, but that it grew considerably weaker in the 1950s and 1960s. Using the Alford-index (Alford 1964) and extending his analysis to the 2003 elections, Harðarson $(1995,2004)$, furthermore, shows that class voting in the 1980s was weak compared to the other Nordic countries and essentially irrelevant from the 1995 election onward. Bengtsson et al. $(2014,36)$ provide a similar conclusion with respect to the early 2000s, finding that Iceland stands out from the other Nordic countries as the least polarized party system in terms of left-right distances between party voters.

\section{The Great Recession and new class voting}

while the traditional class cleavage may have lost its relevance in recent decades, it doesn't imply that occupational class no longer structures political choice in a meaningful manner. Occupations are, for example, important determinants of income, future economic mobility, and employment insecurity, which have long been recognized as strongly affecting political preferences and vote choice (Moene \& Wallerstein 2001; Rehm 2009; 
Helgason \& Merola 2017). As such, one would expect a vertical dimension to the effects of occupational class on political behavior, ranging from low-income workers with limited employment security and career opportunities to high-income workers with relatively safe jobs and well-defined opportunities for career progression (Evans 2000). This vertical dimension is well captured by the Erikson-Goldthorpe-Portocarero (EGP) class schema (Erikson, Goldthorpe, \& Portocarero 1979; Erikson \& Goldthorpe 1992), which has to a large extent superseded the manual/non-manual class dichotomy in studies of class voting (Evans 2017).

More recent studies have, however, also pointed to the existence of a horizontal dimension to occupational class, in addition to the vertical dimension. While the vertical dimension is characterized by differences in organizational authority and marketable skills, the horizontal dimension is based on differences in occupational task structures (Kitschelt \& Rehm 2014). The fundamental premise behind the horizontal dimension is that policy preferences and political behavior are powerfully affected by the work logic individuals employ in their occupation. In this view, there is not a unified "middle class" or a unified "working class", but heterogeneity within each vertical class which is based around the work experiences of individuals embedded in different occupational task structures.

While such task structures can be classified in several ways, Oesch $(2006,2008)$ usefully delineates four work logics which should have differing implications for political preferences and behavior: A technical work logic, an organizational work logic, an interpersonal work logic, and an independent work logic. The defining difference between the work logics are the setting of the work process, its relation to authority, and primary orientation. Thus, for example, individuals who deal with clear-cut command structures and object- or document-related tasks (e.g. managers or production workers), should hold a more authoritarian view of society than individuals who primarily deal with individuals from one day to another in a none structured manner (e.g. social workers or nursing aides). By distinguishing these different work logics, we can begin to understand the heterogeneity often found in the political preferences and behavior of the vertical classes: the middle class and the working class. ${ }^{1}$

Combining the vertical and horizontal dimensions of occupations, Oesch's class schema results in eight different occupational classes: The traditional bourgeoisie and small business owners (independent work logic, high/low skilled), technical professionals and production workers (technical work logic, high/low skilled), managers and clerks (organizational work logic, high/low skilled), and socio-cultural professionals and service workers (interpersonal service work logic, high/low skilled). Importantly, these are not social classes in the traditional sense, which are mobilized around a collective identity, but rather groupings of occupations which, due to their commonalities, share latent interests with respect to the political realm (Oesch 2006). Thus, while class awareness (e.g. Kelley \& Evans 1995; Oddsson 2016) may contribute to increasing class voting, Oesch's (and our) use of the concept is more in line with what Kocka $(1980,104)$ refers to as an "economic class" - a group of individuals who share latent interests due to their common economic position, but not necessarily anything else. 
We argue that the political importance of such a new class schema should be found in the Icelandic case. Thus, rather than experiencing continuing class dealignment, whereby the structuring effects of class on vote choice decreases secularly over time (e.g. Dalton \& Wattenberg 2002), our argument is that while the structuring role of the traditional class cleavage may have decreased, there has been a postindustrial realignment around this new class schema, whereby large parties continue to offer distinctive programmatic platforms which appeal to different classes (Kitschelt \& Rehm 2015). This is by no means the conventional wisdom in studies of Icelandic political behavior. Indeed, recent sophisticated contributions have argued that Icelandic voters have moved further into the Michigan funnel of causality for vote choice (Campbell et al. 1960) suggesting that the importance of structural cleavages has declined, with issue voting and electionspecific factors now playing a more important role in voting behavior (Önnudóttir et al. 2017). The perceived irrelevance of the economic cleavage to vote choice can furthermore be gauged in another recent top-level contribution, which doesn't mention either "income" or "class" in their analysis of vote choice in the 2013 Icelandic parliamentary election (Indriðason, Önnudóttir, Pórisdóttir, \& Harðarson 2017). On the contrary, we argue for the importance of such economic factors, centered on the new class schema, which leads to our first hypothesis:

Hypothesis 1: A new class schema, based on a vertical dimension of marketable skills and a horizontal dimension of occupational task structure, shapes party choice in Icelandic politics.

The specific aspects of the vertical and horizontal dimensions of the class schema, lead to two hypothesized dimension based around occupational class (Oesch 2008). First, a vertical dimension based on differences in economic resources, which pits the holders of organizational power (traditional bourgeoisie and managers) against the working class (production workers and service workers). Second, a horizontal dimension based on cultural differences, which pits high-skilled individuals working in an interpersonal setting (socio-cultural professionals) who hold a libertarian view of society against those occupied in an object-oriented setting (production workers) who hold an authoritarian view of society (Oesch 2008).

As Oesch, we expect the first dimension to primarily affect the support of conservative parties, and parties of the traditional left, which in the Icelandic context should primarily affect the Conservative Independence Party and the left-wing Left-Green Movement and Social Democrats. The second dimension, however, should primarily affect support for parties which advocate economic and cultural openness, one the one hand, and parties which take a firm position against such openness, on the other hand, which in the Icelandic context should primarily pit together the left-wing Social Democrats and Liberal Bright Future and Reform Party against the more Conservative Independence Party and Center-Rural Progressive Party. This leads to the following hypotheses: 
Hypothesis 2a: There is an economic-based occupational dimension in Icelandic politics between the traditional bourgeoisie and managers, on the one hand, and service workers and production workers, on the other hand.

Hypothesis 2b: There is a cultural-based occupational dimension in Icelandic politics between socio-cultural professionals, on the one hand, and production workers, on the other hand.

Should we expect an economic crisis of the magnitude of the Great Recession and the ensuing political crisis to affect the strength of occupationally-based voting? From a micro-level, bottom-up, perspective of class voting, there is little reason to expect such a shift. Factors which have been used to explain the decline of class voting from a bottom-up perspective, such as increasing social mobility, affluence, individualization, and education, generally operate on a gradual basis, over the long-term. However, if we accept a macro-level, top-down, approach to class voting, where the actions of political actors and the ideological range of options they collectively present to voters play a primary role, an economic crisis of the size of the Great Recession can potentially realign voters on the basis of class.

There are two primary mechanisms by which an economic crisis can bring about such a realignment, both of which operated in the Icelandic case following the Great Recession. First, economic crises commonly bring about the need for painful austerity measures, as government revenue falls and government spending increases. As Grittersová, Indridason, Gregory, and Crespo (2016) highlight in a different context, how austerity measures are structured inevitably bring about policy decisions framed along the socioeconomic dimension: Should the government cut spending, which often involves reducing welfare state generosity and cutting the wages of public employees, or should it raise taxes, shifting the burden on those with higher incomes? To the extent that an incumbent government is forced to pursue such austerity measures, it is likely to increase the range of ideological positions offered by competing parties in the following election, and, thus, allowing the class dimension to structure political choice to a larger extent.

Second, as argued by Hernández and Kriesi (2016) a major crisis, such as the Great Recession, may lead to a substantial change in the structure and equilibrium of a party system in a given country. In the context of the present argument, an economic crisis may facilitate the formation of new political parties which implicitly mobilize voters on the basis of their latent occupational interests. Thus, while traditional political parties might be unlikely to rebrand themselves abruptly with respect to given economic interests (e.g. due to their prior issue positions or track record while in office), new parties are not bound by such a past. To the extent that an economic crisis brings about the emergence of new political parties, it is likely to accelerate the realignment of the party system around new dimensions of contention.

Importantly, while the former mechanism might be considered to have a transient 
effect on class voting (i.e. when the economy improves, partisan conflict over economic issues should decrease in importance) the latter mechanism suggests that a crisis, such as the Great Recession, may have more longer-term implications for class voting. The key aspect of the argument is that party systems are generally stable with limited potential of existing parties to rebrand themselves with respect to economic issues and limited opportunities for new parties representing distinct platforms to emerge onto the stage. A large economic crisis can act as a "critical juncture" for such a stable party system, increasing the possibility for new parties to emerge and, as such, potentially transform the dimensions of political conflict between different political parties. As should be clear, this mechanism is thus not analogous to the cyclical nature of economic voting (e.g. Duch \& Stevenson 2008), but rather suggest a longer term structural change in the relationship between occupational class and vote choice.

We hypothesize that the overwhelming effect of the 2008 economic crisis, commonly referred to as the starting point of the Great Recession, on Icelandic society, served as such a realigning event. The crisis involved the failure of several major financial institutions and is considered one of the largest financial collapses in world history, in relation to the size of the economy (Helgason, forthcoming). On the economic front, the crisis brought about increases in unemployment and economic insecurity, a massive devaluation of the currency, and the introduction of spending cuts and tax raises by the government (Ólafsson 2016). On the political front, the economic crisis generated a full blown political crisis, with trust in political parties and government plummeting, large scale street protests, and electoral volatility greatly increased between elections (Bernburg 2016; Indriðason et al. 2017; Önnudóttir et al. 2017). The vote share of new parties in Iceland, furthermore, increased exponentially in the post-crisis years. Thus, newly formed parties gained $8 \%$ of the vote in $2009,25 \%$ in 2013 , and a massive $38 \%$ in the 2016 election. Of these new parties, four gained representation in parliament: The Citizens' Movement in 2009, The Pirate Party in 2013 and 2016, Bright Future in 2013 and 2016, and the Reform Party in 2016. The first two parties both emphasized radical democratic reforms and a rejection of "politics as usual" in their electoral campaigns, while the latter two are advocates of social and economic liberalism. Thus, although none of the new parties have explicitly mobilized voters around a specific occupational dimension, their distinctive platforms, both vis-à-vis each other, but also with respect to the established parties, could tap into latent occupational interests in different ways.

Based on the size of the economic crisis and the increasing support for newly formed parties, we hypothesize that the Great Recession brought about a realignment along the lines of the new class schema in Iceland, increasing its importance in voting behavior. While such a realignment could take place in the immediate aftermath of the crisis, there are reasons to expect that there might be some delay between the onset of the crisis and its effect on the party system. This is both because austerity is not implemented immediately following an economic crisis - 2009-2012 were the main austerity years in the Icelandic case - but also because the formation of new parties around latent economic interests is unlikely to occur in a short period of time. As such, we offer two hypotheses 
for the effects of the Great Recession on class voting in Iceland, albeit we find that latter hypothesis more plausible.

Hypothesis 3a: The Great Recession immediately led to stronger occupational class voting in Iceland. Class voting should, thus, be stronger from 2009 onward, than in the years prior to the crisis.

Hypothesis 3b: The Great Recession led to stronger occupational class voting in Iceland with delay. Class voting should, thus, be stronger from 2013 onward, than in the years prior to the crisis.

\section{Data and methods}

To test the abovementioned hypotheses, we use survey data from the Icelandic National Election Study (ICENES), which has been fielded after every parliamentary election in Iceland since 1983 (ICENES Database n.d.). The survey is based on a representative sample of the voting-eligible population, with the sample size ranging from 1400 to 2600 in each survey. Early on the response rate was around $70 \%$ but in later years it has declined somewhat and has been around $55 \%$ in the last couple of elections. ${ }^{2}$ We pool data from all survey years with available data. Due to the specific nature of our measure of occupational class, we can only test the new class hypotheses using data from 1999 onward. The overall sample size is, thus, 5,203 respondents from six elections.

The dependent variable used in the analysis is the respondent's self-reported voting behavior in the preceding parliamentary election. Since we are interested in the relationship between occupational class and vote choice, we exclude non-voters from the analysis, and only include parties which have gained seats in parliament. We further classify vote choice based on the "party family" voted for in an election (Lane \& Ersson 1999), an approach commonly used in studies of cleavage strength (e.g. Brooks, Nieuwbeerta, \& Manza 2006; de Graaf, Jansen, \& Need 2013; Hobolt 2013). Classifying parties in families is done to ensure comparability over the entire time period, as well as allowing for the inclusion of smaller parties.

Given the dominance of the "four-party model" in Iceland, each of the four main parties in Icelandic politics forms a separate category. This includes the Left-Green Movement (a left-wing party, i. Vinstribreyfingin - grant frambod), the Social Democratic Alliance (a center-left party, i. Samfylkingin), the Progressive Party (a centric-rural party: historically, an agrarian party, i. Framsóknarflokeurinn), and the Independence party (a conservative party, i. Sjálfstadisflokkurinn). Two additional categories are included to capture other parties which have gained seats in parliament during the period: Firstly, a liberal party category, which includes Bright Future (2013-16, i. Björt framtíf) and the Reform Party (2013-16, i. Vidreisn), and is characterized by economic and social liberalism and pro-Europeanism. Secondly a category for other parties, which are not easily classified within the other party families. This includes the Liberal Party (1999-2007, i. Frjálslyndi flokekurinn), the Citizens' Movement (2009, i. Borgarahreyfingin), and the Pirate 


\section{STJÓRNSÝSLA}

Party (2013-16, i. Piratar). The first party mostly emphasized changes to the Icelandic fisheries system (and wasn't a consistent advocate of social and economic liberalism, despite its name), while the latter two are characterized by a rejection of mainstream parties and support for more direct democracy over representative democracy.

The main independent variable in the analysis is occupational class. Classifying respondents based on Oesch's 8-fold class schema is, however, not straightforward, since the ICENES dataset does not consistently include a fine grained measure of occupation (see Oesch 2006, 2008). In particular, while Oesch's class scheme to a large part requires 2 digit ISCO codes to correctly classify respondents into classes, the ICENES dataset only includes 1 digit codes for some of the years from 1999. It is possible, however, to map class positions using the 1 digit ISCO-codes, along with several other variables, including whether the respondent is self-employed, his/her education level, and public or private sector employment. While using such an approximation induces some measurement error, out of sample testing suggests it gives a satisfactory representation of the underlying class schema. ${ }^{3}$

All models include controls for age, gender, urban/rural residence, and education (primary, secondary, or tertiary), as well as fixed effects for each election year. The control variables are included in the models to ensure that any relationship we find between class and vote choice are not due to these more fundamental factors, while at the same time not introducing post-treatment bias into the model (i.e. each variable could plausibly cause variation in occupation, while occupation would hardly cause variation in any of the control variables).

When testing hypotheses on changes over time, we interact the class variables with the relevant measure of time, as detailed below. While other factors, such as individual values, issue positions and evaluations of parties and leaders surely matter for party choice, they are not included in the analysis, since they are unlikely to confound the relationship between our primary independent variable of interest, class, and the outcome of interest, vote choice. Furthermore, since part of the effect of class on party choice might be mediated through such variables, including them in the statistical analysis would unnecessarily bias the effect of class downwards.

\subsection{Methods}

We test the hypotheses using multinomial logistic regression, with vote choice regressed on control variables and year fixed effects in the baseline specification. ${ }^{4}$ To evaluate whether the new class schema offers any explanatory power, we contrast a model with no class measure (model 1) with a model which includes dummy variables for each of the eight classes (model 2). To test whether the effects of this new class measure changes over time, we estimate three models with temporal interactions. First, we estimate a model (model 3) with all eight classes interacted with a dummy for the post economic collapse period (takes on the value of 1 for the years 2009, 2013, and 2016). Second, we estimate a model (model 4) with all eight classes interacted with a dummy for the post crisis period (takes on a value of 1 for the year 2013 and 2016). Lastly, we estimate 
a model (model 5) which allows for unconstrained changes in the effects of class over the different years included in the sample $(8$ classes each interacted with 6 election year dummies).

Each of the models are fairly complex (8 classes and 6 party families), with no single coefficient in each model corresponding to the hypotheses being tested. However, since the models are nested (model 5 being the most general, model 1 the most restrictive), we use a likelihood ratio test to evaluate which model fits the data best. Simply put, the null hypothesis of the likelihood ratio test is that the restriction imposed by the more restrictive model of two models is valid (i.e. the coefficient(s) being excluded from the model equal zero). Rejection of the null hypothesis implies we should prefer the more general model over the more restrictive model. The test statistic generated by the test follows a chi-square distribution, with degrees of freedom equal to the number of restrictions imposed (Greene 2003).

\subsection{Measuring cleavage strength}

The likelihood ratio tests allow us to determine which models best fit the data and, thus, test the main hypotheses put forward in this paper. However, they do not give us any indication of the magnitude or direction of change in the effects of class on vote choice. To allow for such an evaluation, one has to construct a cleavage voting indicator, which can summarize the overall effect of class on voting. The relatively simple and straightforward Alford-index (Alford 1964) is, perhaps, the best known of such measures of cleavage strength, although in later years more sophisticated measures have been developed, with the Kappa-index (Hout, Brooks, \& Manza 1995) being the most widely used measure of cleavage strength in class voting research in recent years (Knutsen 2013).

In this paper, however, we use a measure based on a strategy developed by Duch and Stevenson (2008) and extended by Helgason (2016), which is similar in spirit to the Kappa-index, although it goes beyond it in several ways. ${ }^{5}$ Like the Kappa-index, the measure is based on the coefficients from the preferred model of party choice, selected with the method outlined above. However, whereas the Kappa index uses a single hypothetical "modal" individual to calculate differences in the predicted probabilities of different party choices associated with different classes, the method used here calculates the changes in predicted probabilities for the covariate profiles of each and every member of the sample. This approach has the advantage of giving a better representation of the underlying extent of class voting, since the hypothetical "modal" individual does not necessarily give a good representation of the underlying population (Train 2003). This is especially important in cases with many combinations of values (e.g. with eight classes and six party choice outcomes in samples of size 600-1000, the number of observations within each combination are quite few), since such covariate profiles may lead to highly variable coefficient estimates, which may lead to volatile estimates of cleavage strength.

The process of compiling the measure is as follows: After estimating the preferred model of party choice, we calculate the predicted probability of each respondent voting for each party choice. We then simulate a change in the class variable for each re- 


\section{STJÓRNSÝSLA}

spondent (e.g. from production worker to manager) holding all other covariates fixed, recalculate the predicted probabilities, and find the change in predicted probabilities for voting for each party associated with a change in the class variable. We do this for each of the occupational classes (e.g. for the new class variable, we simulate changes to seven different classes), each time generating a set of values for changes in predicted probabilities for each party. We then square the values (so that all values are positive), sum over each value separately for each year, and then standardize by dividing by the number of changes in classes, number of party choices, and number of respondents. Finally, we take the square root of the resulting value and multiply by 100 . Due to similarities with the Kappa-index, we call this measure "Full Kappa", as it calculates the Kappa-index based on all respondents in a sample, rather than merely a hypothetical "model" individual. The equation for the yearly value of the Full-Kappa measure is:

$$
\mathrm{FK}_{t}=\left[\frac{1}{N J(C-1)} \sum_{n=1}^{N} \sum_{j=1}^{J} \sum_{c=1}^{C-1}\left(\hat{P}_{t n j\left(c !=c^{*}\right)}-\hat{P}_{t n j\left(c=c^{*}\right)}\right)^{2}\right]^{1 / 2} \times 100
$$

where $t$ stands for time, $n$ for respondents ( $\mathrm{N}$ for number of respondents), $j$ for party choice ( $\mathrm{J}$ for number of parties), and $c$ for classes ( $\mathrm{C}$ for number of classes). Finally, $\mathrm{c}^{*}$ stands for the class an individual belongs to, with

$$
\hat{P}_{t n j\left(c !=c^{*}\right)}-\hat{P}_{t n j\left(c=c^{*}\right)}
$$

capturing the difference in predicted probability of a specific party choice, when class is changed to any other class than $\mathrm{c}^{*}$.

Intuitively, the indicator captures the extent to which the predicted probabilities of each party choice is sensitive to changes in the class variable. In cases where the class variable is uncorrelated with party choice, changes in the predicted probabilities will be small and the resulting value for the indicator will be small. However, when class is highly predictive of vote choice, changes in the class variable will lead to substantial changes in the predicted probabilities and, consequently, a large Full-Kappa value. Like the Kappa-index, the Full Kappa measure can theoretically take on values from 0 (no difference) to 50 (full divergence). ${ }^{6}$

Like the Kappa-index, the Full-Kappa measure can be extended in several ways. In the analysis that follows, we take advantage of this possibility by creating a party specific Full-Kappa measure, which captures the extent to which support for each party is polarized based around occupational class, i.e. the extent to which a party's support among occupational classes diverges (as opposed to being uniform among different classes). To do so, we follow the strategy above, but rather than summing over all voting outcomes, we sum over each voting outcome separately.

Finally, to estimate the uncertainty of the above measures, we bootstrap confidence 


\section{STJÓRNSÝSLA}

intervals around the mean predicted value (Carsey \& Harden 2013). Thus, we draw a thousand samples of observations from the data with replacement and repeat the process outlined above for each of the samples. ${ }^{7}$ This gives us a thousand values for the yearly Full Kappa measure, which can be used to construct a confidence interval around the mean predicted value. Although constructing confidence intervals in this fashion is fairly conservative (i.e. we do not impose any normality constraint on the coefficients and are thus more likely to get wide intervals), this does give some indication for whether yearly fluctuations are within the margin of error of prior years or whether they are of significance.

\section{Analysis}

As the models being estimated are fairly large, we focus on reporting summary statistics of the models and graphical representation of the results. The appendix includes full regression results for the preferred model. In the appendix, we also provide an analysis of traditional class voting using the methodology outlined above. The results reaffirm prior research based on the Alford-index showing the increasing irrelevance of traditional class voting in the Icelandic case (Harðarson 1995, 2004).

However, is it the case that class no longer matters? Table 1 contrasts five models that test the hypotheses that there is a new class schema of relevance in Icelandic politics and whether the Great Recession has caused a realignment around this new schema. A comparison of models 1 and 2 allows us to evaluate the hypothesis that class matters for party choice, while a comparison of models 3 and 4, with model 2 allows us to evaluate the hypothesis that the effect of class changed following the Great Recession. Finally, comparing model 5 with model 4 shows whether unconstrained fluctuations over time (model 5) better characterize the development of class voting over time than a single shift following the Great Recession (model 4).

We start by comparing models 1 and 2 which, respectively, include no measure of class and then Oesch's 8 class schema. A likelihood ratio test suggests we should reject the hypothesis that class has no effect on party choice $(\mathrm{p} \approx 0.00)$, which supports hypothesis 1 . Thus, we can say with confidence that there continues to be an occupational structure to party choice in Icelandic politics. 
Table 1. New Class Voting in Iceland, 1999-2016

\begin{tabular}{lccccc}
\hline & Model $\mathbf{1}$ & Model $\mathbf{2}$ & Model 3 & Model 4 & Model 5 \\
\hline $\begin{array}{l}\mathbf{8} \text { class measure included? } \\
\text { Interacted with time? }\end{array}$ & No & Yes & Yes & Yes & $\begin{array}{c}\text { Yes } \\
\text { N }\end{array}$ \\
Nagelkerke R & 5203 & 5203 & 5203 & 5203 & 5203 \\
LR-test vs. Model $\mathbf{1}\left(\boldsymbol{x}^{2}\right.$ test stat.) & 0.284 & 0.301 & 0.307 & 0.308 & 0.326 \\
LR-test vs. Model 2 $\left(\boldsymbol{x}^{2}\right.$ test stat.) & & $117.3^{*}$ & $161.3^{*}$ & $166.9^{*}$ & $293.1^{*}$ \\
LR-test vs. Model $\mathbf{4}\left(\boldsymbol{x}^{2}\right.$ test stat.) & & & 44.0 & $49.6^{*}$ & 175.8 \\
\hline
\end{tabular}

$+\mathrm{p}<0.10, * \mathrm{p}<0.05$ (P-values refer to the results of the LR-test). Summary statistics from multinomial logistic regressions. DV: Party family voted for. Model includes year fixed effects and controls for, age, gender, urban/rural residence, and education.

Did the Great Recession alter the strength of this cleavage? Models 3, 4, and 5 offer tests of whether the effects of class on voting behavior changes over time: Model 3 tests hypothesis $3 \mathrm{a}$, which predicts that the effects of class have changed in the post-collapse period (2009-16); model 4 tests hypothesis 3b, which predicts that the effects of class have changed in the post-crisis period (2013-16); and model 5 tests whether trendless fluctuation has dominated.

Comparing each of the models to model 2, which assumes a constant effect for class, suggests a specific temporal pattern to class voting. We cannot reject the null hypothesis in the case of model 3 ( $p=0.12$ ), while we can reject the null hypothesis of no change in the case of model $4(\mathrm{p}=0.04)$. Thus, the data indicate that the effects of class have changed significantly in the 2013 and 2016 elections from prior years, with the pattern in the 2009 election being more similar to the pre-collapse period than the post-collapse period. This is perhaps unsurprising, since the early crisis period offered little opportunity for parties to radically change their party platforms and realign voters along new lines. Finally, comparing model 4 and 5 suggests that trendless fluctuation does not fit the data better than a one-off shift in the post-crisis period $(p=0.80)$. Overall, thus, model 4 is our preferred model, which supports hypothesis $3 \mathrm{~b}$, while counting as evidence against hypothesis 3 a. 


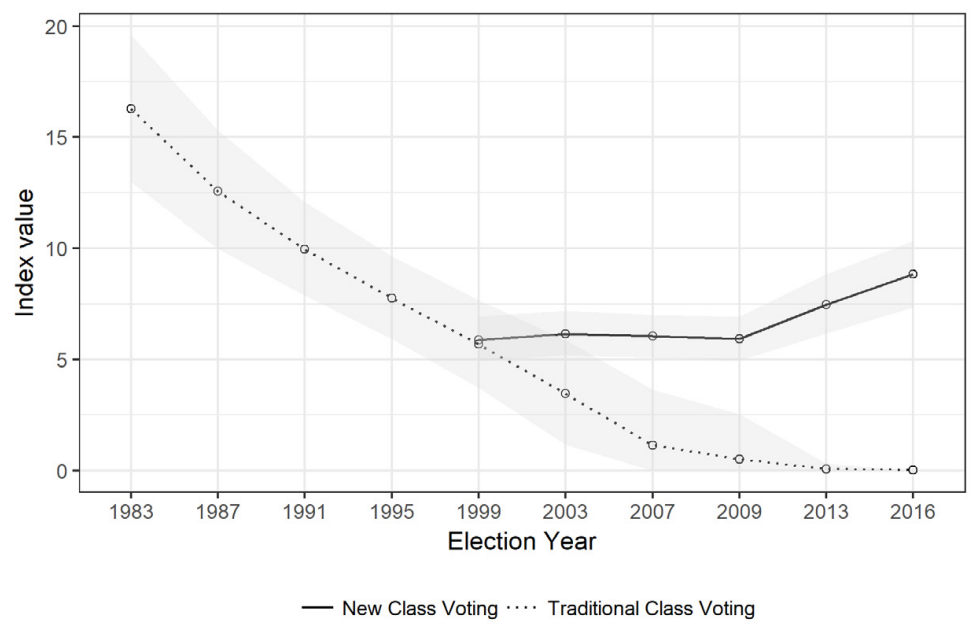

Figure 1. Traditional and new class voting in Iceland, 1983-2016

Note: Both measures include $90 \%$ bootstrapped confidence intervals. Analysis for traditional class voting shown in appendix.

Figure 1 shows the Full Kappa measure for new class voting based on model 4, with traditional class voting shown for comparison. Two things stand out from the figure. First, new class voting was relatively stable before the crisis, hovering around a low value of 6, which is similar to the extent of traditional class voting in 1999. Second, after the crisis, new class voting has increased substantially, first to a value of 7.5 in 2013 and then to a value of 9 in 2016. This is a substantial increase, shifting new class voting to a similar level as traditional class voting was between 1991 and 1995. Importantly, this suggests that while new class voting remains less important than traditional class voting in earlier years, it still matters for voting behavior in Icelandic politics, and its importance has grown following the crisis. There is, thus, some indication that class politics in Iceland have shifted from a state of dealignment to some realignment around the new class schema.

\subsection{Partisan differences in class voting}

Do all parties contribute to polarization around class or are there specific parties which mobilize voters, at least implicitly, around occupational class? Figure 2 attempts to shed light on this question by showing the development of the party specific Full Kappa measure for the six different party families. The measure reflects the extent to which the predicted probabilities of voting for particular party families changes as we simulate changes to the class variable of respondents in the sample. Several factors in the figure warrant attention. 

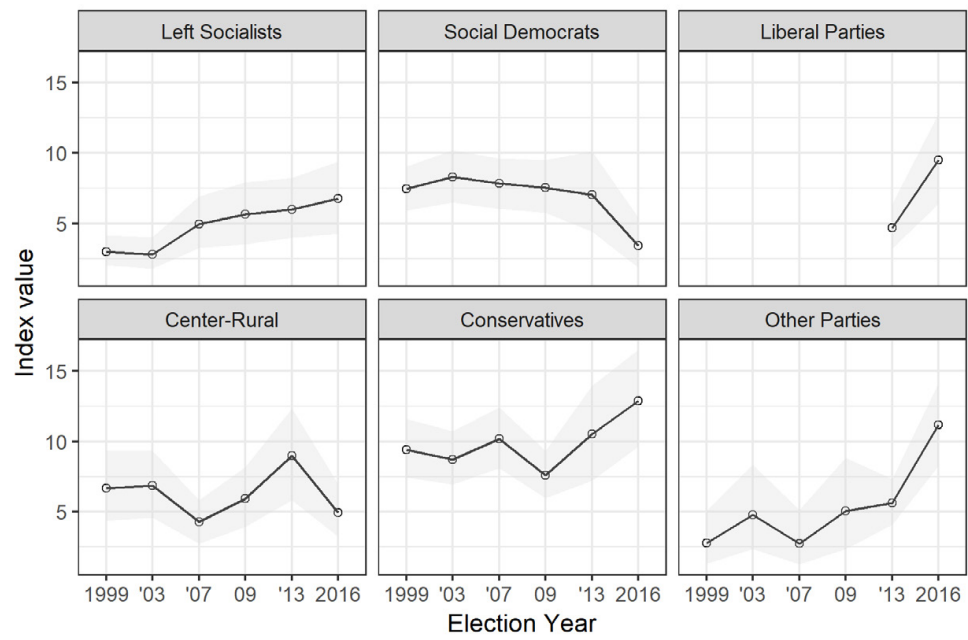

Figure 2. Party-specific new class voting, 1999-2016

Note: All measures include 90\% bootstrapped confidence intervals. Liberal Parties: Bright Future (2013-16) and the Reform Party (2016). Other Parties: The Liberal Party (1999-2007), the Citizens' Movement (2009), and the Pirate Party (2013-16).

First, in the pre-crisis period class voting was strongest for the Social Democrats (Social Democratic Alliance) and Conservatives (Independence Party), with the Left Socialists (Left-Green Movement), Center-Rural (Progressive Party), and Others (Liberal Party) showing less intense forms of class voting. This is, perhaps, unsurprising as the first two parties dominated Icelandic politics in the run-up to the 2008 crisis. After the crisis, a new pattern has emerged. As the popularity of the Social Democrats has waned, so has their polarizing effect. This is to some extent driven by how the measure of class voting is calculated, as, by definition, large parties have the potential to be more polarizing than small parties. The opposite is true of the Conservative Independence Party, which were more polarizing in the 2016 election than in any other election in the period in question, with the impact of class going from moderate to strong from 2007 to 2016. The Pirate Party (only party under "Other Parties" in 2013 and 2016), similarly, has become substantially polarizing in class voting. The extent of class voting for the Left Socialist Left Green Movement has increased slightly over the period in question, while the new class appeal of the Center-Rural Progressive Party has fluctuated somewhat erratically. Finally, the newly formed liberal parties seem to contribute somewhat to the strength of class voting, especially in the 2016 election, when the impact of class was considerable.

Figures 3 and 4 show the occupational profiles of parties in more detail for the 2007 and 2016 elections, respectively, based on the results of model 4. The figures show how much different from the sample mean the predicted probability of voting for particular parties are for particular classes, with a black fill indicating statistical significance at the $10 \%$ level. 


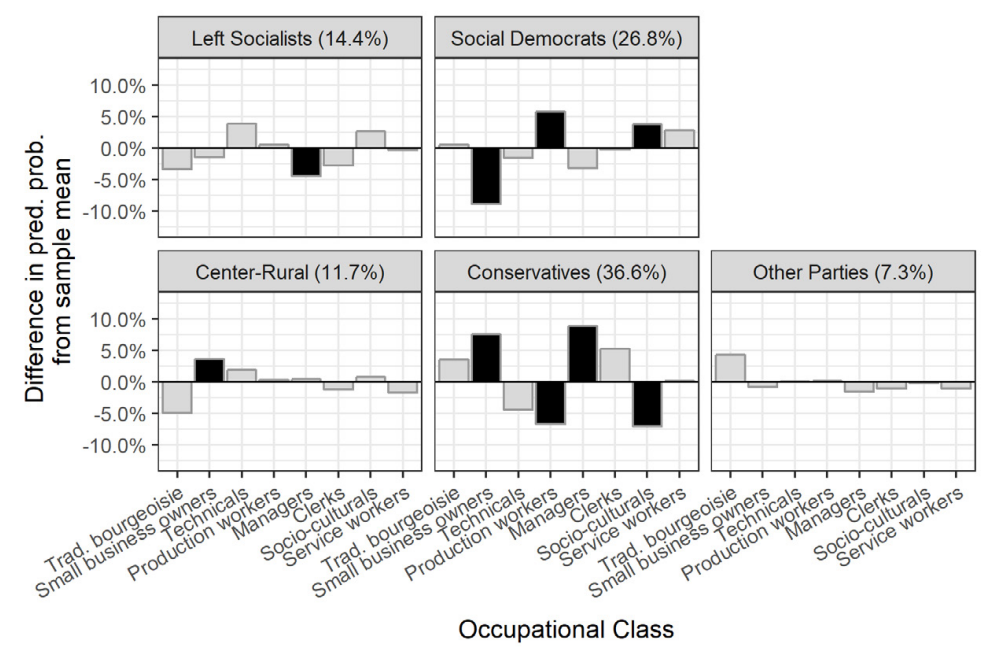

Figure 3. Occupational voting profiles of party families in 2007

Note: Black fill indicates statistical significance at the $10 \%$ level, based on bootstrapped confidence intervals. Percentage in each header shows vote share of each party family in the 2007 election. Other Parties: The Liberal Party.

Starting with figure 3 , small business owners ( $2^{\text {nd }}$ bar from left in each subfigure) are clearly the most polarizing occupational class in 2007 . They were about $9 \%$ less likely to vote for the Social Democrats than the sample mean, while being about $4 \%$ and $8 \%$ more likely to vote for the Center-Rural Progressive party and Conservative Independence Party, respectively. There is also a significant divergence in the voting behavior of production workers ( $4^{\text {th }}$ bar from left), with the Social Democrats and Conservatives again being the polarizing parties. Thus, production workers were $6 \%$ more likely to vote for the former party and 7\% less likely to vote for the latter party, than the average employed voter. A similar divergence presents itself when analyzing the voting behavior of socio-cultural professionals ( $7^{\text {th }}$ bar from left), with the occupational group being $4 \%$ more likely to vote for the Social Democrats and 7\% less likely to vote for the Conservatives, than average. Of the remaining occupational classes, only the support of managers $\left(5^{\text {th }}\right.$ bar from left) for the Left Socialist Left Green Movement and the Conservative Independence Party stand out as significant, with managers being 5\% less likely than average to vote for the former party and $8 \%$ more likely to vote for the latter party.

Overall, the occupational voting profiles in 2007 suggest two primary dimension of contention. First, a somewhat strong economic dimension between managers and production workers, which manifest in differing levels of support for the two left-wing parties on the one hand and for the Conservative Independence Party on the other hand. Second, there is a clear middle class split between socio-cultural professionals, on the one hand, and small business owners, on the other hand, which primarily manifests itself in differences in support for the two largest parties, the Social Democrats and Conservatives. Thus, one could say that new class voting in 2007 was primarily based 
around these two parties, with the Social Democrats forming a coalition of production workers and socio-cultural professionals, and the Conservatives of small business owners and managers. As suggested by figure 2, other parties were much less polarizing in terms of occupational class.

Figure 4 suggests that in 2016, nine years onwards from 2007, there is some continuity in the occupational voting profiles of the different party families, but also that substantial changes have occurred on some cases. To begin with, the Conservatives are again the most polarizing party and seem to be even more polarizing than in the 2007 elections, as suggested by figure 2. In 2016, three occupational classes diverge by over $10 \%$ from the sample mean in their voting behavior for the party: The traditional bourgeoisie ( $1^{\text {st }}$ bar from left) were $12 \%$ more likely to vote for the party than the other classes, while socio-cultural professionals and service workers ( $8^{\text {th }}$ bar from left) were $12 \%$ and $11 \%$ less likely to vote for the party than average, respectively.

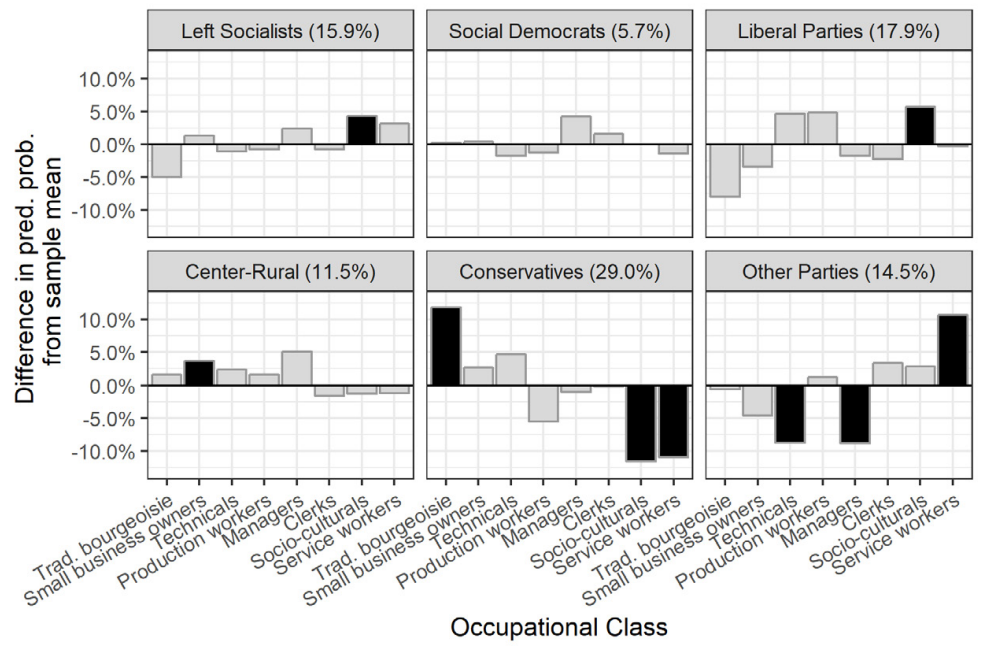

Figure 4. Occupational voting profiles of party families in 2016

Note: Black fill indicates statistical significance at the $10 \%$ level, based on bootstrapped confidence intervals. Percentage in each header shows vote share of each party family in the 2016 election. Liberal Parties: Bright Future and the Reform Party. Other Parties: The Pirate Party.

Interestingly, the latter two occupational classes diverge in whom they are more likely to vote for. While both classes eschew the Conservative Independence Party, socio-cultural professionals allocate their votes to a larger extent towards the Left-Green Movement (Left Socialists) and the newly formed Bright Future and Reform Party (Liberal Parties), while service workers overwhelmingly support the Pirate Party (Other Parties). Countering their strong support among service workers, the Pirate Party is opposed more by technical professionals ( $3^{\text {rd }}$ bar from left) and managers, on average, than by the sample mean. The only other statistically significant difference is the support for small business owners for the Progressive Party (Center- Rural). 
Overall, the occupational voting profiles in 2016 suggest the existence of two dimensions of contention, albeit somewhat changed from 2007. First, a strong economic dimension between managers and the traditional bourgeoisie, on the one hand, and service workers, on the other hand. This is a change from 2007, with the primary difference being that production workers showed the opposite behavior to managers in 2007, while service workers were more divergent in 2016. Second, and to a lesser extent, there continuous to be a middle class split between socio-cultural professionals and small business owners, with the former showing strong support for the Left Socialists and Liberal Parties, and the latter being more likely to support the Center-Rural Progressive Party and Conservatives.

Thus, the evidence for hypotheses $2 \mathrm{a}$ and $2 \mathrm{~b}$ are mixed. Support for hypothesis $2 \mathrm{a}$ is somewhat strong. There is clearly an economically-based occupational cleavage in Icelandic politics, with the traditional bourgeoisie and managers opposing service workers and/or production workers in their voting behavior. There is less support, however for hypothesis $2 \mathrm{~b}$. In 2007, both socio-cultural professionals and production workers showed similar voting behavior. In 2016, there are less similarities, but hardly enough difference to suggest that the two occupational classes vote in opposite directions. Instead, there seems to be a durable difference in the voting behavior of socio-cultural professionals and small business owners. Overall, thus, we consider hypothesis 2a supported, while we reject hypothesis $2 \mathrm{~b}$.

\section{Conclusion}

The preceding analysis suggests that class is not irrelevant to Icelandic politics. While our findings support prior research on the decline of traditional class voting, there clearly exists a new class schema which affects party choice to some extent. Moreover, the strength of this cleavage has increased following the Great Recession, with increasing divergence in the voting behavior of occupational classes. Throughout the period under study, the Conservative Independence Party has been the most polarizing party in terms of class, with its occupational voting profile becoming even more polarizing following the economic crisis. Newly formed parties also seem to have contributed to increasing class voting, with the Pirate Party showing similar levels of class divergence in the 2016 election as the Independence Party. Overall, this suggest that an individual's occupational class is still relevant to party choice in Iceland and studies of vote choice should account for an individual's economic position in their analysis.

What are the implications of these results for the future of Icelandic politics? First, there are clear signs of increasing class voting following the Great Recession with the data suggesting that the crisis may have contributed to realigning voters to with respect to class. This is not least so because the crisis facilitated the emergence of new parties that have successfully tapped into the latent class interests of different occupational groups. During the same time, the class profile of the formerly dominant Independence Party has become much more homogenous, with the party now appealing strongly to the traditional bourgeoisie occupational class and less so to service workers and sociocultural professionals. 
As Hernández and Kriesi (2016) suggest, there is reason to believe that such changes caused by the Great Recession can have longer-term implications - i.e. that the crisis to some extent exogenously "shocked" a stable party system, changing its composition drastically. Thus, the changes brought about by the Great Recession may well have caused a realignment, in which a durable, programmatic difference in interests between different occupational groups becomes manifest in the party system.

Such speculations are, however, necessarily tentative, not least since we are still merely a decade removed from the onset of the crisis. Thus, it might be the case that the changes observed are temporary, perhaps being driven by the short-term salience of inequality and concerns for economic security, which may subside as time passes. The success of newly formed parties may, furthermore, be ephemeral, with traditional parties regaining ground in future elections. Only time will tell if that is the case.

A natural next step is to extent the present analysis with comparative data. The hypotheses presented on the effects of the Great Recession on class voting suggests that we should observe increasing polarization along the lines of class in countries hit hard by the crises and more so in countries with permissive electoral systems, with lower barriers for new parties to gain seats in parliament. With the economic conflict following the recession providing the impetus and new parties the vehicle for mobilization around latent occupational interests, there is reason to believe that increases in class voting should not be isolated to the Icelandic case.

\section{Acknowledgements}

Thanks to participants at the Nordic Political Science Congress in 2017 and two anonymous reviewers for helpful comments. This work was supported by the Icelandic Research Fund (Grant No. 173968-052).

\section{Notes}

1 For a more detailed discussion of the theoretical foundations of the class schema, see Oesch (2006, 2008) .

2 We have no reason to expect changes in the response rates to affect the evaluation of the relationship between vote choice and occupational class.

3 Part 3 of the appendix shows how the original variables from the ICENES dataset were recoded into Oesch's 8 class schema. To gauge how well this approximation captures the underlying class schema, we use the same method on Icelandic respondends from the 2012 European Social Survey (ESS, 2012). Since the 2012 ESS data contains all the necessary variables to faithfully create Oesch's 8 class schema, we can compare how well the approximation does in classifying respondents in Iceland. Overall, approximately $80 \%$ of respondents are correctly classified based on the method used here, which we expect to hold in the ICENES data as well. While such measurement error due to incomplete data is unfortunate, it should work against finding systematic relationships between variables in the following analysis, and, in any case, provide a lower bound to the effect of class on voting.

4 In the appendix, we provide an analysis of the traditional class decline hypothesis using the same methodology.

5 Duch and Stevenson use the indicator to measure the effects of the economy on vote choice, while Helgason uses it to measure the effects of income on vote choice. 
6 A simplified example for illustrative purposes: Say there are two occupational classes, A and B, and three parties, $\mathrm{X}, \mathrm{Y}$ and $\mathrm{Z}$. To calculate the measure of cleavage strength, we run a conventional multinomial logistic regression and calculate the change in predicted probabilities of each vote choice $\mathrm{X}, \mathrm{Y}$ and $\mathrm{Z}$ when we change the value of the class variable from $\mathrm{A}$ to $\mathrm{B}$ (or vice versa). If class has a large explanatory value for vote choice, the change in predicted probability of voting for each party will be large for different classes. As an example, a switch from A to B might make one, on average, $30 \%$ less likely to vote for X, 20\% more likely to vote for $\mathrm{Y}$ and $10 \%$ more likely to vote for $\mathrm{Z}$. However, if class has a small explanatory value for vote choice, the change in predicted probabilities will only change slightly. As an example, a switch from A to B might make one, on average, $3 \%$ less likely to vote for $\mathrm{X}, 2 \%$ more likely to vote for $\mathrm{Y}$ and $1 \%$ more likely to vote for $\mathrm{Z}$. This calculation is repeated for every covariate profile in the sample and summed over all occupational groups and all vote choice outcomes to arrive at the full Kappa measure. A large full Kappa measure will thus reflect large changes in predicted probabilities associated with a change in the class variable, while a small full Kappa measure will reflect the opposite.

7 We stratify each bootstrap sample by year and class, so that the sample size of each class and each year remains identical in all draws.

\section{References}

Alford, R.R. (1964). Party and Society: The Anglo-American Democracies. London, UK: Rand McNally.

Bengtsson, Å., Hansen, K.M., Harðarson, Ó.P., Narud, H.M., and Oscarsson, H. (2014). The Nordic Voter: Myths of Exceptionalism. Colchester, UK: ECPR Press.

Bernburg, J.G. (2016). Economic Crisis and Mass Protest: The Pots and Pans Revolution in Iceland. London, UK: Routledge.

Brooks, C., Nieuwbeerta, P., and Manza, J. (2006). "Cleavage-Based Voting Behavior in Cross-National Perspective: Evidence from Six Postwar Democracies”, Social Science Research 35(1), 88-128.

Campbell, A., Converse, P.E., Miller, W.E., and Stokes, D. (1960). The American Voter. New York, NY: John Wiley and Sons.

Carsey, T.M., and Harden, J.J. (2013). Monte Carlo Simulation and Resampling Methods for Social Science. Thousand Oaks, CA: Sage Publications.

Clark, T.N., and Lipset, S.M. (eds.) (2001). The Breakdown of Class Politics: A Debate on Post-Industrial Stratification. Washington, D.C: Woodrow Wilson Center Press.

Dalton, R.J., and Wattenberg, M.P. (eds.) (2000). Parties Without Partisans. New York, NY: Oxford University Press.

de Graaf, N.D., Jansen, G., and Need, A. (2013). "The Political Evolution of Class and Religion: An Interpretation for the Netherlands, 1971-2006”, in G. Evans and N.D. de Graaf (eds.), Political Choice Matters: Explaining the Strength of Class and Religious Cleavages in Cross-National Perspective (pp. 205-242). Oxford, UK: Oxford University Press.

Duch, R.M., and Stevenson, R.T. (2008). The Economic Vote: How Political and Economic Institutions Condition Election Results. Cambridge, UK: Cambridge University Press.

Erikson, R., and Goldthorpe, J.H. (1992). The Constant Flux: A Study of Class Mobility in Industrial Societies. Oxford, UK: Oxford University Press.

Erikson, R., Goldthorpe, J.H., and Portocarero, L. (1979). "Intergenerational Class Mobility in Three Western European Societies: England, France and Sweden”, British Journal of Sociology 30(4), 415441.

ESS (2012). European Social Survey Round 6 Data. Data file edition 2.3, Norwegian Social Science Data Services, Norway.

Evans, G. (1999). The end of class politics?: class voting in comparative context. USA: Oxford University Press..

Evans, G. (2000). "The continued significance of class voting", Annual Review of Political Science 3(1), 401-417. 


\section{STJÓRNSÝSLA}

Evans, G. (2017). "Social Class and Voting”, in K. Arzheimer, J. Evans, and M.S. Lewis-Beck (eds.), The SAGE Handbook of Electoral Behaviour (pp. 177-198). London, UK: Sage Publications.

Evans, G., and de Graaf, N.D. (eds.) (2013). Political Choice Matters: Explaining the Strength of Class and Religious Cleavages in Cross-National Perspective. Oxford, UK: Oxford University Press.

Franklin, M.N., Mackie, T.T., and Valen, H. (1992). Electoral Change: Responses to Evolving Social and Attitudinal Structures in Western Countries. Cambridge, UK: Cambridge University Press.

George, A.L., and Bennett, A. (2005). Case Studies and Theory Development in the Social Sciences. MA: MIT Press.

Greene, W.H. (2003). Econometric Analysis (6 $6^{\text {th }}$ ed.). Upper Saddle River, NJ: Prentice Hall.

Grittersová, J., Indridason, I.H., Gregory, C.C., and Crespo, R. (2016). "Austerity and niche parties: The electoral consequences of fiscal reforms", Electoral Studies 42, 276-289.

Harðarson, Ó.P. (1995). Parties and Voters in Iceland: A Study of the 1983 and 1987 Althingi Elections. Reykjavik, Iceland: Social Science Research Institute.

Harðarson, Ó.P. (2004). "Kjósendur og stéttir á Íslandi 1983-2003 [Voters and Classes in Iceland 19832003]”, in Ú. Hauksson (ed.), Rannsóknir i félagsvísindum VI (pp. 613-625). Reykjavík, Iceland: Háskóli Íslands.

Häusermann, S., and Kriesi, H. (2015). "What Do Voters Want? Dimensions and Configurations in Individual-Level Preferences and Party Choice", in P. Beramendi, S. Häusermann, H. Kitschelt, and H. Kriesi (eds.), The Politics of Advanced Capitalism (pp. 202-230). New York, NY: Cambridge University Press.

Helgason, A.F. (forthcoming). "Government Responses to the Great Recession: A Comparative Perspective", in S. Ólafsson, M. Daly, O. Kangas, and J. Palme (eds.), Welfare and the Great Recession: A Comparative Study. Oxford, UK: Oxford University Press.

Helgason, A.F. (2016). "Income-Based Voting and Polarization Over Redistribution Under Alternative Electoral Systems", Electoral Studies 42, 22-32.

Helgason, A.F., and Merola, V. (2017). "Employment Insecurity, Incumbent Partisanship, and Voting Behavior in Comparative Perspective", Comparative Political Studies 50(7), 1489-1523.

Hernández, E., and Kriesi, H. (2016). "The electoral consequences of the financial and economic crisis in Europe", European Journal of Political Research 55(2), 203-224.

Hobolt, S.B. (2013). "Enduring Divisions and New Dimensions: Class Voting in Denmark", in G. Evans and N.D. de Graaf (eds.), Political Choice Matters: Explaining the Strength of Class and Religious Cleavages in Cross-National Perspective (pp. 185-204). Oxford, UK: Oxford University Press.

Hout, M., Brooks, C., and Manza, J. (1995). “The Democratic Class Struggle in the United States, 19481992”, American Sociological Review 60(6), 805-828.

ICENES Database (n.d.). Retrieved from http:// fel.hi.is/icelandic_national_election_study_icenes

Indriðason, I.H., Önnudóttir, E.H., Pórisdóttir, H., and Harðarson, Ó.P. (2017). "Re-electing the Culprits of the Crisis? Elections in the Aftermath of a Recession", Scandinavian Political Studies 40(1), 28-60.

Kelley, J., and Evans, M.D.R. (1995). "Class and Class Conflict in Six Western Nations", American Sociological Review 60(2), 157-78.

Kitschelt, H., and Rehm, P. (2014). "Occupations as a Site of Political Preference Formation", Comparative Political Studies 47(12), 1670-1706.

Kitschelt, H., and Rehm, P. (2015). "Party Alignments. Change and Continuity", in P. Beramendi, S. Häusermann, H. Kitschelt, and H. Kriesi (eds.), The Politics of Advanced Capitalism (pp. 179-201). New York, NY: Cambridge University Press.

Knutsen, O. (2006). Class Voting in Western Europe: A Comparative Longitudinal Study. London, UK: Lexington Books.

Knutsen, O. (2013). "Structural determinants of party choice: The changing impact of socio-structure variables on party choice in comparative perspective", in W.C. Müller and H.M. Narud (eds.), Party Governance and Party Democracy (pp. 175-203). New York, NY: Springer-Verlag. 


\section{STJÓRNSÝSLA}

Kocka, J. (1980) "The Study of Social Mobility and the Formation of the Working Class in the 19th Century", Le Mouvement Social 111, 97-118.

Lane, J.E., and Ersson, S. (1999). Politics and Society in Western Europe (4th ed.). Thousand Oaks, CA: Sage Publications.

Lipset, S.M. (1981). Political Man: The Social Bases of Politics (Original work published 1960). London, UK: Heinemann.

Lipset, S.M., and Rokkan, S. (1967). Party Systems and Voter Alignments: Cross-National Perspectives. New York, NY: Free Press.

Manza, J., and Brooks, C. (2008). "Class and Politics", in A. Lareau and D. Conley (eds.), Social Class: How Does it Work? (pp. 201-31). New York, NY: Russell Sage Foundation.

Manza, J., Hout, M., and Brooks, C. (1995). "Class voting in capitalist democracies since World War II: dealignment, realignment, or trendless fluctuation?”, Annual Review of Sociology 21, 137-162.

Moene, K.O., and Wallerstein, M. (2001). "Inequality, Social Insurance, and Redistribution", American Political Science Review 95(4), 859-874.

Oddsson, G. (2016). "Neoliberal Globalization and Heightened Perceptions of Class Division in Iceland", The Sociological Quarterly 57, 462-490.

Oesch, D. (2006). Redrawing the Class Map. Stratification and Institutions in Britain, Germany, Sweden and Switzerland. Basingstoke, UK: Palgrave Macmillan.

Oesch, D. (2008). "The Changing Shape of Class Voting", European Societies 10(3), 329-355.

Ólafsson, S. (2016). “The Strategy of Redistribution: Iceland's Way Out of the Crisis”, in V. Ingimundarson, P. Urfalino, and I. Erlingsdóttir (eds.), Iceland's Financial Crisis: The Politics of Blame, Protest, and Reconstruction (pp. 156-182). London, UK: Routledge.

Önnudóttir, E.H., Schmitt, H., and Harðarson, Ó.P. (2017). "Critical Election in the Wake of an Economic and Political Crisis: Realignment of Icelandic Party Voters?", Scandinavian Political Studies 40(2), 157-181.

Rehm, P. (2009). "Risks and Redistribution: An Individual-Level Analysis", Comparative Political Studies $42(7), 855-881$.

Streeck, W. (2009). Re-Forming Capitalism: Institutional Change in the German Political Economy. Oxford, UK: Oxford University Press.

Train, K. (2003). Discrete Choice Methods with Simulation. New York, NY: Cambridge University Press. 



\section{Appendix for "The Great Recession and New Class Voting in Iceland"}

\section{Part 1: Traditional Class Voting}

The weaknesses of the Alford-index are well known, which has led researchers to apply ever more sophisticated measures to the study of class voting (Manza et al., 1995). Since such a measure has not been applied to the Icelandic case, we evaluate the decline of traditional class voting in the Icelandic case in the appendix. Based on the theoretical discussion in the main paper, as well as previous findings by Harðarson (2004), we expect a trend of decline in traditional class voting in the Icelandic case. From the formation of the modern Icelandic party system, particular parties explicitly mobilized voters on the basis of class, with survey evidence suggesting high levels of class voting around the middle of the 20th century (Harðarson, 2004). Similarly, the mechanisms outlined in the paper leading to declining class voting have all been at work in the Icelandic case.

To test the traditional decline hypothesis, we dichotomize party choice, coding responses into the two categories of "Voted for left-wing party" and "Voted for non-left wing party". Parties which were explicitly founded to represent the interests of the working class, their successors, and minor split-off parties, are classified as left-wing parties. This includes the Social Democratic Party and the People's Alliance from 1983 to 1995, their successors, the Social Democratic Alliance and the Left-Green Movement from 1999 to 2016, and the split off parties Alliance of Social Democrats in 1983 and 1987 and National Awakening in 1995. All other parties are classified as non-left wing parties.

In the evaluation of the traditional decline hypothesis, occupational class is dichotomized into manual workers and non-manual workers on the basis of a corresponding variable included in the ICENES dataset.

We follow the same methodology as in the main paper to evaluate whether class voting has changed over time, with vote choice regressed on traditional class, control variables, and year fixed effects in the baseline specification (model A.1). We evaluate two additional models to test whether the effects of class changes over time: First, we interact the class variable with a continuous measure of time (model A.2). Secondly, we interact the class variable with a dummy variable for each of the election years (model A.3). We continue comparing models of increasing complexity using the likelihood ratio test.

1 The exclusion of the minor split-off parties as left-wing parties does not alter the results presented in the paper. 
Table A.1. Traditional Class Voting in Iceland, 1983-2016

\begin{tabular}{lccc}
\hline & Model A.1 & Model A.2 & Model A.3 \\
\hline 2 class measure included? & Yes & Yes & Yes \\
Interacted with time? & No & Linear & Unconstrained \\
$\mathrm{N}$ & 9061 & 9061 & 9061 \\
Nagelkerke R2 & 0.055 & 0.059 & 0.060 \\
LR-test vs. Model 1 $\left(\boldsymbol{x}^{2}\right.$ test stat.) & & $32.0^{*}$ & $34.7^{*}$ \\
LR-test vs. Model 2 $\left(\boldsymbol{x}^{2}\right.$ test stat.) & & & 2.7 \\
\hline
\end{tabular}

$+\mathrm{p}<0.10,{ }^{*} \mathrm{p}<0.05$. Logistic regression results. DV: Voted for Left party? Model includes year fixed effects and controls for, age, gender, urban/rural residence, and education. See Table A.2 for full results.

Has traditional class voting remained constant, declined linearly, or fluctuated with no apparent trend from 1983 onward? Table A.1 shows a comparison of three models representing each of these different scenarios: Model A.1 represents the case of a "constant effect", model A.2 represents the case of "traditional decline", and model A.3 a case of "trendless fluctuation". Comparing the models using a likelihood ratio test, we find that model A.2 offers an improvement over model A.1 ( $\mathrm{p} \approx 0.00)$, while model A.3 does not improve upon model A.2 ( $\mathrm{p}=0.95)$. Thus, the "traditional decline" model fits the data best, as suggested by previous research.

Figure A.1 shows the Full Kappa measure calculated on the basis of model A.2. Class voting started out at the relatively large value of 16 in 1983 and has progressively become smaller. From 2007 it has been statistically insignificant from 0 and in the 2013 and 2016 elections, the measure is exactly 0 , indicating that non-manual workers are now more likely to vote for left-wing parties than manual workers. ${ }^{2}$

2 Note that since we are testing the traditional decline hypothesis, which indicates a specific direction in class voting (manual workers becoming relatively less likely to vote for left-wing parties), we do not allow for the possibility of non-manual workers being more likely to vote for left-wing parties, as seems to be the case. If we did allow for such a pattern, the Full Kappa indicator would show a slight increase in 2013 and 2016, which would not indicate a resourgence in traditional class voting, but the exact opposite. 


\section{STJÓRNSÝSLA}

Figure A.1. Traditional Class Voting in Iceland, 1983-2016

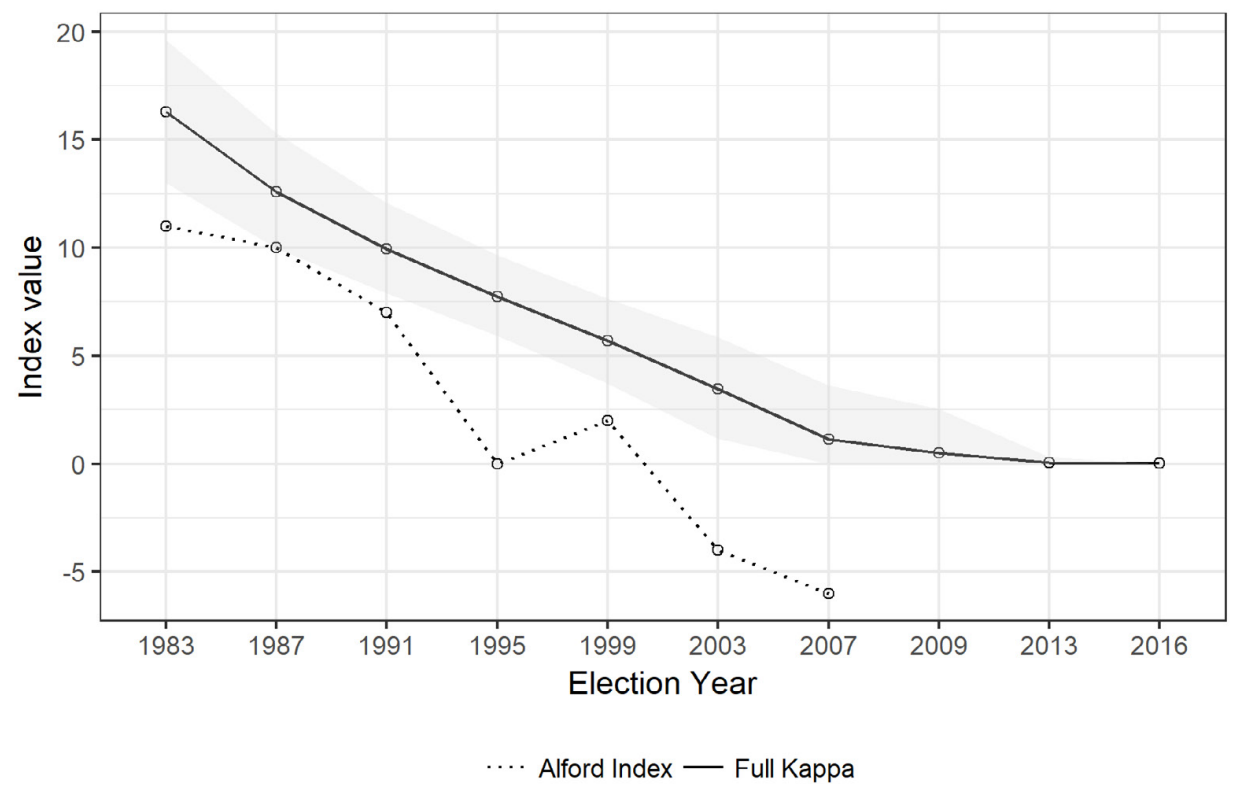

Note: Full Kappa measure includes 90\% bootstrapped confidence interval.

For comparison, we include the Alford-index calculated by Harðarson (2004) and extended in Bengtsson et al. (2014). While the two indicators are not measured on the same scale, their trend is similar in its decline. Since the Alford-index is calculated separately for each election, it shows a more volatile relationship than our preferred model. However, as model A.2 fits the data as well as model A.3 (which allows for unconstrained change), we employ that as the basis for our calculations. 
Table A.2 Full Results from Table A.1

\begin{tabular}{|c|c|c|c|}
\hline & Model 1 & Model 2 & Model 3 \\
\hline \multirow[t]{2}{*}{ Manual workers (Non-manual = ref.) } & $1.352^{*}$ & $2.046^{*}$ & $2.098^{*}$ \\
\hline & $(5.65)$ & (7.87) & (4.64) \\
\hline \multirow[t]{2}{*}{ Age } & $1.003^{*}$ & $1.003^{*}$ & $1.003^{*}$ \\
\hline & $(2.05)$ & $(2.00)$ & $(1.97)$ \\
\hline \multirow[t]{2}{*}{ Female? } & $1.515^{*}$ & $1.480^{*}$ & $1.480^{*}$ \\
\hline & (8.53) & $(8.01)$ & $(8.01)$ \\
\hline \multirow[t]{2}{*}{ Rural residence? } & $0.876^{*}$ & $0.884^{*}$ & $0.884^{*}$ \\
\hline & $(-2.81)$ & $(-2.60)$ & $(-2.60)$ \\
\hline \multicolumn{4}{|l|}{ Education (Secondary = ref.): } \\
\hline \multirow[t]{2}{*}{ - Primary education } & 0.961 & 0.960 & 0.961 \\
\hline & $(-0.74)$ & $(-0.75)$ & $(-0.72)$ \\
\hline \multirow[t]{2}{*}{ - Tertiary education } & $1.603^{*}$ & $1.543^{*}$ & $1.546^{*}$ \\
\hline & $(7.22)$ & $(6.60)$ & $(6.63)$ \\
\hline \multicolumn{4}{|l|}{ Linear change (year centered on 1983): } \\
\hline \multirow[t]{2}{*}{ - Manual X Year (Cont.) } & & $0.972^{*}$ & \\
\hline & & $(-5.61)$ & \\
\hline \multicolumn{4}{|l|}{ Unconstrained change (1983 = ref.): } \\
\hline \multirow[t]{2}{*}{ - Manual x 1987} & & & 0.923 \\
\hline & & & $(-0.39)$ \\
\hline \multirow[t]{2}{*}{ - Manual x 1991} & & & 0.808 \\
\hline & & & $(-0.99)$ \\
\hline \multirow[t]{2}{*}{ - Manual x 1995} & & & $0.620^{*}$ \\
\hline & & & $(-2.31)$ \\
\hline \multirow[t]{2}{*}{ - Manual x 1999} & & & $0.616^{*}$ \\
\hline & & & $(-2.32)$ \\
\hline \multirow[t]{2}{*}{ - Manual x 2003} & & & $0.513^{*}$ \\
\hline & & & $(-3.09)$ \\
\hline \multirow[t]{2}{*}{ - Manual x 2007} & & & $0.467^{*}$ \\
\hline & & & $(-3.52)$ \\
\hline \multirow[t]{2}{*}{ - Manual x 2009} & & & $0.537^{*}$ \\
\hline & & & $(-2.72)$ \\
\hline \multirow[t]{2}{*}{ - Manual x 2013} & & & $0.401^{*}$ \\
\hline & & & $(-3.77)$ \\
\hline \multirow[t]{2}{*}{ - Manual x 2016} & & & $0.461^{*}$ \\
\hline & & & $(-2.54)$ \\
\hline \multirow[t]{2}{*}{ Intercept } & $0.444^{*}$ & $0.359^{*}$ & $0.354^{*}$ \\
\hline & $(-8.84)$ & $(-10.18)$ & $(-8.38)$ \\
\hline 2 class measure included? & Yes & Yes & Yes \\
\hline Interacted with time? & No & Linear & Unconstrained \\
\hline $\mathrm{N}$ & 9061 & 9061 & 9061 \\
\hline AIC & 11363 & 11333 & 11347 \\
\hline Nagelkerke R2 & 0.055 & 0.059 & 0.060 \\
\hline LR-test vs. Model 1 (Chi 2 test stat.) & & $32.0^{*}$ & $34.7^{*}$ \\
\hline LR-test vs. Model 2 (Chi 2 test stat.) & & & 2.7 \\
\hline
\end{tabular}

$+\mathrm{p}<0.10,{ }^{*} \mathrm{p}<0.05$. Logistic regression results. DV: Voted for Left party? Exponentiated coefficients. t-stat. in parentheses. Model includes year fixed effects (not shown). 
STJÓRNSÝSLA

\section{Part 2 Full Results from the Preferred Model 4 in Table 1 in Main Paper} Table A.3

\begin{tabular}{|c|c|c|c|c|c|}
\hline & Left Soc. & Soc. Dem. & Other & Liberals & Agrarians \\
\hline \multicolumn{6}{|l|}{ Social Class (Managers = ref.): } \\
\hline \multirow[t]{2}{*}{ - Traditional bourgeoisie } & 0.220 & 0.260 & $1.082^{*}$ & -0.0574 & -0.568 \\
\hline & $(0.48)$ & $(0.87)$ & $(2.05)$ & $(-0.00)$ & $(-1.00)$ \\
\hline \multirow[t]{2}{*}{ - Small business owners } & 0.275 & -0.239 & 0.240 & 0.359 & 0.287 \\
\hline & $(1.00)$ & $(-1.21)$ & $(0.67)$ & $(0.00)$ & $(1.31)$ \\
\hline \multirow[t]{2}{*}{ - Technical Professionals } & $0.898^{*}$ & $0.386^{+}$ & $0.702^{+}$ & 0.285 & 0.439 \\
\hline & $(2.92)$ & $(1.65)$ & $(1.66)$ & $(0.00)$ & $(1.53)$ \\
\hline \multirow[t]{2}{*}{ - Production Workers } & $0.768^{*}$ & $0.711^{*}$ & $0.798^{*}$ & 0.654 & 0.354 \\
\hline & $(2.90)$ & $(3.87)$ & $(2.35)$ & $(0.00)$ & $(1.63)$ \\
\hline \multirow[t]{2}{*}{ - Clerks } & 0.234 & 0.203 & 0.240 & 0.0383 & -0.113 \\
\hline & $(0.80)$ & $(1.00)$ & $(0.60)$ & $(0.00)$ & $(-0.44)$ \\
\hline \multirow[t]{2}{*}{ - Socio-cultural professionals } & $0.911^{*}$ & $0.654^{*}$ & $0.731^{*}$ & 0.292 & $0.402^{+}$ \\
\hline & $(3.51)$ & $(3.60)$ & $(2.01)$ & $(0.00)$ & $(1.70)$ \\
\hline \multirow[t]{2}{*}{ - Service workers } & $0.529^{*}$ & $0.425^{*}$ & 0.349 & 0.255 & -0.0397 \\
\hline & $(2.00)$ & $(2.31)$ & $(0.98)$ & $(0.00)$ & $(-0.18)$ \\
\hline \multicolumn{6}{|c|}{ Social class X Year Dummy (1999-2009 = ref.) } \\
\hline \multirow[t]{2}{*}{ - Trad. bourg. x 2013-16 } & -0.910 & -0.259 & $-2.106^{*}$ & -0.879 & 0.151 \\
\hline & $(-1.44)$ & $(-0.48)$ & $(-2.86)$ & $(-0.00)$ & $(0.21)$ \\
\hline \multirow[t]{2}{*}{ - Small bus. x 2013-16 } & -0.317 & 0.539 & $-1.399^{*}$ & -0.771 & -0.255 \\
\hline & $(-0.86)$ & $(1.32)$ & $(-3.07)$ & $(-0.00)$ & $(-0.78)$ \\
\hline \multirow[t]{2}{*}{ - Tech. x 2013-16 } & $-1.121^{*}$ & -0.593 & $-2.498^{*}$ & -0.381 & -0.608 \\
\hline & $(-2.46)$ & $(-1.15)$ & $(-3.45)$ & $(-0.00)$ & $(-1.42)$ \\
\hline \multirow[t]{2}{*}{ - Prod. work. x 2013-16 } & $-0.655^{+}$ & -0.467 & $-1.183^{*}$ & -0.419 & -0.281 \\
\hline & $(-1.83)$ & $(-1.13)$ & $(-3.11)$ & $(-0.00)$ & $(-0.89)$ \\
\hline \multirow[t]{2}{*}{ - Clerks x 2013-16 } & -0.319 & 0.347 & -0.663 & -0.277 & -0.413 \\
\hline & $(-0.77)$ & $(0.83)$ & $(-1.34)$ & $(-0.00)$ & $(-0.98)$ \\
\hline \multirow[t]{2}{*}{ - Soc. cult. x 2013-16 } & -0.280 & 0.118 & $-0.748^{+}$ & 0.247 & -0.441 \\
\hline & $(-0.88)$ & $(0.34)$ & $(-1.87)$ & $(0.00)$ & $(-1.30)$ \\
\hline \multirow[t]{2}{*}{ Age } & 0.00183 & $0.0109^{*}$ & -0.00382 & -0.00472 & 0.00139 \\
\hline & $(0.57)$ & $(4.21)$ & $(-0.95)$ & $(-0.76)$ & $(0.48)$ \\
\hline \multirow[t]{2}{*}{ Female? } & $0.672^{*}$ & $0.549^{*}$ & $-0.316^{*}$ & 0.288 & 0.129 \\
\hline & $(6.55)$ & $(6.41)$ & $(-2.32)$ & $(1.62)$ & (1.34) \\
\hline \multirow[t]{2}{*}{ Rural residence? } & $0.357^{*}$ & 0.0183 & -0.140 & $-0.796^{*}$ & $1.112^{*}$ \\
\hline & (3.69) & $(0.22)$ & $(-1.11)$ & $(-3.95)$ & $(12.37)$ \\
\hline \multicolumn{6}{|l|}{ Education (Secondary = ref.): } \\
\hline \multirow[t]{2}{*}{ - Primary education } & 0.134 & 0.102 & 0.0333 & 0.0885 & $0.208^{*}$ \\
\hline & $(1.10)$ & $(1.02)$ & $(0.23)$ & $(0.35)$ & $(2.02)$ \\
\hline \multirow[t]{2}{*}{ - Tertiary education } & $0.260^{+}$ & $0.375^{*}$ & $-0.539^{*}$ & 0.150 & $-0.240^{+}$ \\
\hline & $(1.94)$ & $(3.29)$ & $(-2.91)$ & $(0.65)$ & $(-1.76)$ \\
\hline \multirow[t]{2}{*}{ Intercept } & $-1.146^{*}$ & $-2.564^{*}$ & 0.253 & -0.165 & $-1.648^{*}$ \\
\hline & $(-3.16)$ & $(-6.74)$ & $(0.58)$ & $(-0.00)$ & $(-4.68)$ \\
\hline 8 class measure included? & Yes & & & & \\
\hline Interacted with time? & $2013-16$ & & & & \\
\hline $\mathrm{N}$ & 5203 & & & & \\
\hline AIC & 15102 & & & & \\
\hline Nagelkerke R2 & 0.308 & & & & \\
\hline
\end{tabular}

$+\mathrm{p}<0.10, * \mathrm{p}<0.05$. DV: Party family voted for (columns represent different outcomes). Reference category: Conservatives. Model includes year fixed effects (not shown). 


\title{
Part 3 Occupational Class Measure
}

The following table shows how the occupational class measure is derived from original variables in the ICENES dataset measuring occupation (variable isco1d, 1-digit ISCO codes $^{3}$, based on variable mainjobflo10 in ICENES), self-employment (variable selfemployed, dummy coding ${ }^{4}$, based on variable uniwindw in ICENES), education (variable educt, 4 ordered categories ${ }^{5}$, variable education4 in ICENES), and public employment (variable public, dummy coding ${ }^{6}$, based on variables govpriv_m and govpriv_pub in ICENES). Note that because the ICENES dataset does not include a more fine grained measure of occupation, the following is only an approximation to Oesch's $(2006,2008)$ class schema. However, out of sample testing suggests that this approximation has acceptable validity, as discussed in the main text of the article.

\section{8-Class schema constructed}

\author{
1 Self-employed professionals and large employers \\ Respondents with selfemployed=1 AND educ4=4 AND (isco1d=1 OR isco1d=2) \\ 2 Small business owners \\ Respondents with selfemployed=1 AND NOT (educ4=4 AND (isco1d=1 OR isco1d=2)) \\ 3 Technical (semi-)professionals \\ Respondents with isco1d=3 AND selfemployed $=0$ AND (educ4=3 OR educ4 $=4$ ) \\ Respondents with isco1 $d=3$ AND selfemployed $=0$ AND public $=0$ \\ 4 Production workers \\ Respondents with (isco1d=6 OR isco1d=7 OR isco1d=8) AND selfemployed=0 \\ Respondents with isco1 $d=9$ AND selfemployed $=0$ AND public $=0$ \\ 5 (Associate) managers \\ Respondents with isco1d $=1$ AND selfemployed $=0$ \\ 6 Clerks \\ Respondents with isco1d $=4$ AND selfemployed $=0$ \\ 7 Socio-cultural (semi-)professionals \\ Respondents with isco1d $=2$ AND selfemployed $=0$ \\ Respondents with isco $1 \mathrm{~d}=3$ AND selfemployed $=0$ AND public $=1$ AND educ $4=2$ \\ 8 Service workers \\ Respondents with isco $1 \mathrm{~d}=5$ AND selfemployed $=0$ \\ Respondents with isco1d $=9$ AND selfemployed $=0$ AND public $=1$ \\ Respondents with isco $1 \mathrm{~d}=3$ AND educ $4=1$ AND selfemployed $=0$ and public $=1$
}

3 Values: 1 = Managers, 2 = Prefessionals, $3=$ Technicians and Associate Professionals, $4=$ Clerical Support Workers, 5=Services and Sales Workers, $6=$ Skilled Agricultural, Forestry, and Fishery Workers, $7=$ Craft and Related Trades Workers, 8=Plant and Machine Operators, and Assemblers, 9=Elementary Occupations

4 Values: $1=$ Is self-employed, $0=$ Is not self employed

5 Values: 1= Primary Education, $2=$ Secondary Education, $3=$ Vocational Education, $4=$ Tertiary Education

6 Values: $1=$ Is a public employee, $0=$ Is not a public employee 